\title{
Warming increases soil respiration in a carbon-rich soil without changing microbial respiratory potential
}

\author{
Marion Nyberg and Mark J. Hovenden \\ School of Natural Sciences, University of Tasmania, Hobart, 7001, Australia \\ Correspondence: Marion Nyberg (mnybe1@mail.ubc.ca)
}

Received: 24 April 2020 - Discussion started: 25 May 2020

Revised: 28 July 2020 - Accepted: 30 July 2020 - Published: 2 September 2020

\begin{abstract}
Increases in global temperatures due to climate change threaten to tip the balance between carbon (C) fluxes, liberating large amounts of $\mathrm{C}$ from soils. Evidence of warming-induced increases in $\mathrm{CO}_{2}$ efflux from soils has led to suggestions that this response of soil respiration $\left(R_{\mathrm{S}}\right)$ will trigger a positive land $\mathrm{C}$-climate feedback cycle, ultimately warming the Earth further. Currently, there is little consensus about the mechanisms driving the warming-induced $R_{\mathrm{S}}$ response, and there are relatively few studies from ecosystems with large soil C stores. Here, we investigate the impacts of experimental warming on $R_{\mathrm{S}}$ in the C-rich soils of a Tasmanian grassy sedgeland and whether alterations of plant community composition or differences in microbial respiratory potential could contribute to any effects. In situ, warming increased $R_{\mathrm{S}}$ on average by $28 \%$, and this effect was consistent over time and across plant community composition treatments. In contrast, warming had no impact on microbial respiration in incubation experiments. Plant community composition manipulations did not influence $R_{\mathrm{S}}$ or the $R_{\mathrm{S}}$ response to warming. Processes driving the $R_{\mathrm{S}}$ response in this experiment were, therefore, not due to plant community effects and are more likely due to increases in belowground autotrophic respiration and the supply of labile substrate through rhizodeposition and root exudates. $\mathrm{CO}_{2}$ efflux from this high-C soil increased by more than a quarter in response to warming, suggesting inputs need to increase by at least this amount if soil C stocks are to be maintained. These results indicate the need for comprehensive investigations of both $\mathrm{C}$ inputs and losses from $\mathrm{C}$-rich soils if efforts to model net ecosystem $\mathrm{C}$ exchange of these crucial, $\mathrm{C}$-dense systems are to be successful.
\end{abstract}

\section{Introduction}

Globally, more carbon (C) is stored in soils than the amount of $\mathrm{C}$ in the atmosphere and in plants combined (Canadell et al., 2007). Simple physiology suggests that soil respiration $\left(R_{\mathrm{S}}\right)$ rates will increase as soil temperatures rise (Gillooly et al., 2001), stimulating $\mathrm{CO}_{2}$ emissions from the soil - a response that has the potential to outweigh plant productivity responses to global warming and lead to a net loss of $\mathrm{C}$ from soils (Melillo et al., 2017). Recently, numerous studies have suggested that global warming is indeed disturbing the balance between ecosystem $\mathrm{C}$ inputs and outputs (Melillo et al., 2017). This suggests the possibility of a positive feedback, whereby warming increases $\mathrm{C}$ efflux from soils, which accelerates climate change leading to further $\mathrm{C}$ losses. (Bridgham et al., 2008; Melillo et al., 2017; Bond-Lamberty et al., 2018). Importantly, it is possible that warming-induced $C$ losses increase with soil C content, as soils with large C stocks have a greater susceptibility to warming since there is more substrate available for decomposition, and therefore soils storing the most $\mathrm{C}$ could shift from $\mathrm{C}$ sinks to $\mathrm{C}$ sources (Crowther et al., 2016).

Increases in respiration of soil organic carbon (SOC) as an effect of experimental warming occur almost universally (Rustad et al., 2001); however, increasing soil temperatures stimulate not only soil microbes and enzyme activity but also net primary productivity (NPP) and fresh C input from litterfall and root exudations (Rustad et al., 2001), enhancing substrate availability for microbial respiration ( $\mathrm{Lu}$ et al., 2013; Wang et al., 2017). Warming effects have also been demonstrated to drive microbial priming, whereby decomposition is enhanced through increased input of labile $\mathrm{C}$ compounds (van der Wal and de Boer, 2017). Despite this, greater aboveground plant biomass is not directly linked to immediate or 
long-term increases in the storage of SOC, and hence the mechanisms driving the response of $R_{\mathrm{S}}$ to warming are uncertain (Jackson et al., 2017).

The effects of temperature on environmental factors such as soil moisture, substrate availability, and evapotranspiration also influence and mediate rates of decomposition of soil organic matter (SOM) and efflux of $\mathrm{CO}_{2}$ (Davidson et al., 2000; Eliasson et al., 2005; Lu et al., 2013). These effects include extension of growing seasons and shifts in species composition and community structure (Chen et al., 2016). Considering this, changes in plant community composition and subsequent shifts in functional traits have the potential to influence the quantity and quality of organic matter in the soil, as well as the physical soil structure (Metcalfe et al., 2011). For instance, an experiment implementing the CENTURY model revealed significant differences in SOC levels and the carbon to nitrogen ratio of the active SOM fraction between mixed grassland communities and those comprised completely of $\mathrm{C}_{3}$ or $\mathrm{C}_{4}$ vegetation (Epstein et al., 1999; Parton et al., 1987). This suggests that there is potential for the response of soil $\mathrm{C}$ dynamics to warming to be partially or even wholly dependent upon changes to plant community composition (Jackson et al., 2017).

Both experimental and global warming have impacts on soil water availability, which is itself a primary determinant of $R_{\mathrm{S}}$ (Schimel et al., 1994). Following a unimodal relationship, respiration is highest at an intermediate $(35 \%-50 \%$ by volume) soil water content (SWC), which stimulates microbial activity and enhances above- and below-ground labile $\mathrm{C}$ inputs (Chou et al., 2008; Zhou et al., 2010; Wang et al., 2017). Anaerobic conditions in wet and flooded soils suppress microbial activity, slowing decomposition of SOM (Davidson and Janssens, 2006). Low SWC can have a similar effect by reducing microbial activity, restricting soil respiration (Carey et al., 2016). As warming generally leads to lower soil water content (Zhang et al., 2013; Li et al., 2017), the impact on $R_{\mathrm{S}}$ depends upon the underlying soil water content, increasing respiration of wet soils but reducing respiration in drier soils (Almagro et al., 2009). Essentially, the effect of warming on SWC could either offset or exacerbate direct warming effects on soil respiration, potentially disturbing the entire global $\mathrm{C}$ balance.

Substrate availability is another factor that is affected by warming, and thus has the potential to shift the temperature sensitivity of SOM decomposition (Davidson and Janssens, 2006). Largely, increased temperatures lead to the loss of physical or chemical protection of SOM, and thus enhanced microbial respiration of soil organic carbon (SOC) (Davidson and Janssens, 2006). Partitioning SOC into pools as a function of recalcitrance and residence time assists with analysing effects of environmental manipulations on long-term $\mathrm{C}$ storage (Pendall et al., 2011). As C inputs to the soil and consequently into these various pools occur in response to the interplay between rates of NPP, decomposition, climatic conditions, and soil characteristics (Ontl and Schulte, 2012), the fate of SOC is either a transformation into highly recalcitrant humus, important for the stabilisation and long-term storage of SOC, or it is lost to the atmosphere as $\mathrm{CO}_{2}$. Thus, factors such as oxygen availability, substrate quantity and quality, nutrient limitation, and activity of extracellular enzymes are key to the soil respiration response. Carefully controlled laboratory incubations are necessary to eliminate confounding factors and pinpoint the mechanisms driving responses observed in the field (Davidson and Janssens, 2006). Ultimately, distinguishing between the potential driving factors is vital for our ability to model future $\mathrm{C}$ fluxes and to extend the observations from field experiments more widely.

To understand the consequences of warming on soil $\mathrm{C} \mathrm{dy-}$ namics and particularly $R_{\mathrm{S}}$, it is necessary to distinguish between warming-related increases in $R_{\mathrm{S}}$ that are simply due to an increase in the biochemical response of $R_{\mathrm{S}}$ to temperature and potential alterations of the temperature sensitivity of $R_{\mathrm{S}}$ caused by climate warming. The increase in $R_{\mathrm{S}}$ with rising temperature has been widely documented (Luo et al., 2001; Rustad et al., 2001); however, the temperature sensitivity of $R_{\mathrm{S}}$ in soils that have undergone experimental warming is much more variable (Song et al., 2014; Carey et al., 2016). Shifts in the temperature sensitivity under warming are likely to be driven by both changes in microbial community composition and changes in the physical and chemical properties of the soil (Davidson and Janssens, 2006). Additionally, effects of warming such as soil drying affect various ecosystem processes and thus might shift the temperature response of $R_{\mathrm{S}}$ (Carey et al., 2016; Moinet et al., 2018). The effect of temperature on $R_{\mathrm{S}}$ is thus complex, and there are a number of biotic and abiotic factors influencing the response of SOM decomposition to warming. Until these various influences are characterised accurately, projecting future soil C emissions will remain problematic.

Although measurements of soil respiration in situ often demonstrate warming-related increases, the mechanisms behind this response cannot be revealed by simple field observations (Davidson and Janssens, 2006). In particular, it is difficult to distinguish changes in microbial community composition and functioning in response to warming from in situ measurements alone. These changes include acclimation (Luo et al., 2001) or adaptation (Bradford et al., 2008), encompassing both physiological and genetic changes within individuals and species, changes in community structure (Sheik et al., 2011), and a shift towards microbial use of slowly decomposing C (Bracho et al., 2016). Hence, a shift in temperature sensitivity of SOM decomposition is likely to be driven by warming through a change in microbial respiratory potential, expressed as the $\mathrm{CO}_{2}$ mineralisation rate.

Here, we use a manipulative experiment to examine the potential influences of climate change, specifically warming and plant community composition, on soil $\mathrm{C}$ dynamics. We examine soil respiration responses both in situ and in laboratory incubation experiments to disentangle the mechanisms involved in the response of soil respiration to both warming 
and manipulation of the plant community. Specifically, we ask the following questions.

1. Does warming increase soil respiration in a Tasmanian C-rich soil?

2. If so, is this due to changes in microbial respiratory potential?

3. Does altering plant community composition change the response of soil respiration to warming?

\section{Materials and methods}

\subsection{Study site}

All field measurements and soil samples were taken during the Silver Plains warming experiment on the Tasmanian central plateau, Australia $\left(42^{\circ} 09^{\prime} \mathrm{S}, 147^{\circ} 08^{\prime} \mathrm{E} ; 890 \mathrm{~m}\right.$ a.s.l.). The site is a natural grassy sedgeland with an average summer temperature of $16^{\circ} \mathrm{C}$, average winter temperature of $6^{\circ} \mathrm{C}$, and average annual rainfall of $720 \mathrm{~mm}$ (BOM, 2018). Soil at the site is peaty, being an organosol containing on average $8 \mathrm{~kg} \mathrm{Cm}^{-2}$ in the top $10 \mathrm{~cm}$. The vegetation at the site is heavily grazed year round by a range of native vertebrate herbivores, including wallabies, pademelons and wombats, as well as by feral fallow deer, resulting in an extremely low vegetation stature of a few centimetres, with the exception of inflorescences which can extend up to $30 \mathrm{~cm}$ above the ground.

\subsection{Experimental design}

The experiment was set up in the 2014 austral winter as a fully orthogonal, two-factor random block design, with warming and species removal as fixed factors across eight replicate blocks (Fig. 1). The warming chambers were installed in mid-2014 and have remained in place continuously up to the present day (mid-2020). The experiment consists of 40 individual $2 \times 2 \mathrm{~m}$ plots, with $3 \mathrm{~m}$ between each plot. A total of 20 of the plots were warmed year-round using hexagonal polycarbonate open-top chambers (OTC) with an internal diameter of $1.5 \mathrm{~m}$, and the remainder were unwarmed, ambient plots. To investigate the impact of altering plant community composition, the dominant species, Poa gunnii, was removed by plucking in one warmed and one ambient plot (henceforth referred to as "dominant removal" plots) in each block. One warmed and one ambient plot in each block was left untouched (henceforth referred to as "no removal" plots). To control for possible effects of removing biomass during the dominant species removal treatment, we removed biomass from one additional warmed and unwarmed plot in every second block. We removed the same amount of biomass as from the "dominant removal" plots in the same block; however, biomass was removed randomly

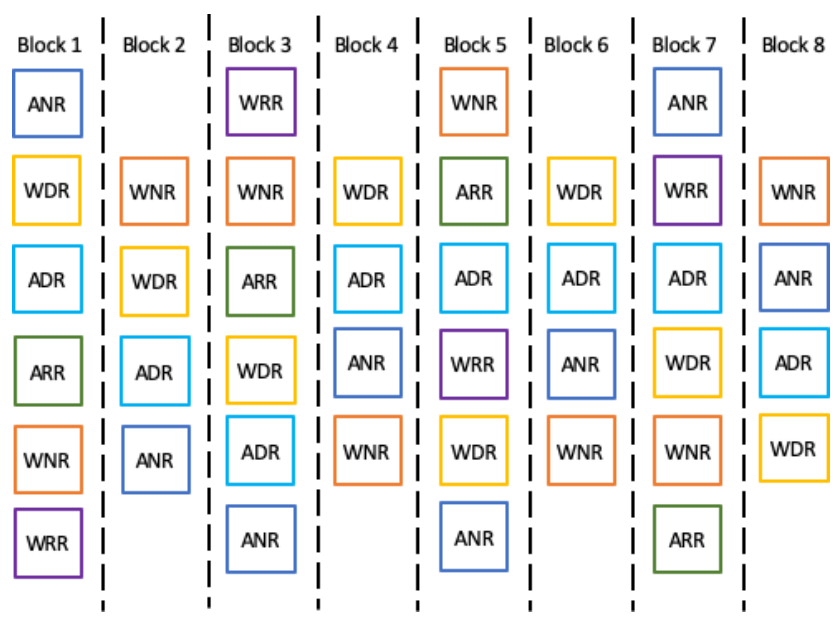

Figure 1. Conceptual diagram for the experimental design of the Silver Plains warming experiment. Each block contains a warmed and unwarmed plot with no species removed (WNR and ANR, respectively); a warmed and unwarmed plot with the dominant species removed (WDR and ADR, respectively); and in every second block, i.e. in four blocks total, there is a warmed and unwarmed plot with random biomass removal (WRR and ARR, respectively).

from across the plot, rather than from a single species (henceforth referred to as "random removal" plots). In both dominant removal and random removal, plucked biomass was completely removed from plots, i.e. not replaced on the plot. Plant biomass was removed in the spring and summer of $2014 / 15$ by gently removing small plants by hand and by repeatedly clipping larger plants to ground level until green shoots no longer emerged. The amount of biomass removed in each plot is presented in Table S1 in the Supplement. After the initial removal treatment, all plots were left undisturbed until the following spring, at which time all plots were surveyed to determine whether removed plants had reestablished. As removed plants had not re-established at this time, no further removal occurred. Plant biomass was not measured directly in the plots in order to reduce disturbance. However, measures of vegetation cover and height indicated that the vegetation in removed plots had recovered completely within 2 years and were very similar to untouched control plots by this time, except in terms of species composition.

Air temperature at $5 \mathrm{~cm}$ height and soil temperature at $5 \mathrm{~cm}$ depth in each plot was logged continuously with iButton data loggers. Over the entire 5-year period, the warming treatment increased air temperature $5 \mathrm{~cm}$ above the soil surface by $1.56^{\circ} \mathrm{C}(P<0.004)$ and soil temperature at $5 \mathrm{~cm}$ depth by $1.29^{\circ} \mathrm{C}(P<0.001)$.

\subsection{In situ methods}

A $50 \mathrm{~mm}$ length of $100 \mathrm{~mm}$ diameter PVC pipe was inserted into the soil to a depth of $2 \mathrm{~cm}$, extending $3 \mathrm{~cm}$ above ground 
height, within the centre $0.25 \mathrm{~m}^{2}$ of each plot for soil respiration measurements. Soil respiration was measured with a $\mathrm{CO}_{2} / \mathrm{H}_{2} \mathrm{O}$ infrared gas analyser (IRGA) (Li-Cor, model LI-6400) with attachment of a Li-Cor 6400-09 soil chamber, which attached to PVC collars. Bare ground is practically non-existent in this ecosystem and the soil is extremely peaty. Therefore, vegetation in collars was not removed but was regularly clipped to just above ground height to minimise the influence of above-ground plant respiration. Our measurement of soil respiration thus did include small contributions of shoot respiration, but as soil at the site is peaty with extensive horizontal root growth, any respiration measurement from this site would include a substantial amount of respiration from belowground plant biomass. Respiration was measured in situ monthly from August 2017 to June 2018. On each occasion, three complete measurements of in situ soil respiration in each plot were averaged and used to define the $\mathrm{CO}_{2}$ efflux rate. The average value of these three measurements was used in subsequent analyses. Soil temperature and moisture in each plot were measured at the exact same time as the soil respiration measurements on each occasion. Soil temperature was measured with a soil thermocouple probe (Li-Cor 6000-09TC) attached to the LI-6400. Volumetric soil water content (SWC) was estimated at five locations in each plot using a handheld time-domain reflectometer1 (TDR) probe at $0-5 \mathrm{~cm}$ depth. Although the organic horizon in this soil is up to $1 \mathrm{~m}$ in depth, the $5 \mathrm{~cm}$ sampling depth is representative for the zone in which most microbial activity occurs in peaty soils (Fisk et al., 2003). The five separate measurements of SWC were then averaged to obtain one SWC value per plot on each measuring occasion.

Six randomly placed soil samples, amounting to a total of approximately $25-30 \mathrm{~g}$ fresh weight, were collected from each plot using a $1.5 \mathrm{~cm}$ diameter hand corer to a depth of $5 \mathrm{~cm}$ below ground level, twice throughout the year. Samples were collected on 2 March 2018, representing the end of summer (or growing season soil), and on 25 June 2018, representing winter soils.

\subsection{Laboratory incubations}

Soil cores collected in situ were immediately placed on ice for return to the laboratory, where they were refrigerated $\left(4{ }^{\circ} \mathrm{C}\right)$ overnight. The following day, the samples were composited at the plot level and sieved through a $4 \mathrm{~mm}$ sieve for $1 \mathrm{~min}$ to remove leaves and large roots. A $10 \mathrm{~g}$ fresh weight subsample was removed and oven dried from each composite sample for the determination of total soil C. Each subsample was ground to a powder in a Retsch Mixer Mill (MM200, Retsch $\mathrm{GmbH}$, Haan) and then $\mathrm{C}$ content was analysed by combustion in a Perkin Elmer 2400 Series II Elemental Analyser (Perkin Elmer Australia, Melbourne). The remaining soil was used immediately for laboratory incubations to determine microbial respiration, as detailed below.
Microbial respiration as a function of temperature was determined by incubation using soils sampled in the Silver Plains warming experiment at the end of summer and in midwinter 2018. For each plot, three replicate samples weighing 4-8 g from the composite sample were placed in $100 \mathrm{~mL}$ specimen jars, each of which was incubated at a different temperature. Each sample was wetted to bring them to $90 \%$ of field capacity for winter soils and $60 \%$ of field capacity for summer soils to represent prevailing soil moisture conditions in each respective season. Once water was added to all soil samples, specimen jars were placed in $500 \mathrm{~mL}$ preserving jars with tightly fitting lids containing a septum to allow gas headspace samples to be collected by syringe. Jars were stored in dark incubation cabinets at temperatures of 10, 17, or $25^{\circ} \mathrm{C}$, with one sample from each plot at each temperature. Headspace gas of jars were sampled $(20 \mathrm{~mL})$ using a syringe on day $1,2,4,5,7,9,12,15,19,23,29,35,49,56$, and 63. After extracting samples from each jar, headspace samples were analysed for $\mathrm{CO}_{2}$ concentration, representing soil respiration, and microbial respiratory potential was thus defined as the rate of $\mathrm{CO}_{2}$ release. To analyse headspace gas, samples were injected directly into an infrared gas analyser (LI-6262, Li-Cor, Lincoln, NE, USA). After measurements were taken and analysed, jars were ventilated for $20 \mathrm{~min}$ and headspace gas equilibrated with atmospheric air. Following this, lids were replaced and headspace gas was sampled and analysed again to obtain the starting $\mathrm{CO}_{2}$ concentration for each jar. $\mathrm{C}$ mineralisation over the sample period was calculated from the increase in headspace $\mathrm{CO}_{2}$ concentration.

Total $\mathrm{C}$ mineralisation over the entire incubation period was simply the sum of the amount of $\mathrm{C}$ mineralised over each sample period. Daily $\mathrm{C}$ mineralisation results $(\mathrm{d} C / \mathrm{d} t)$ were analysed using non-linear curve fitting routines in $\mathrm{R}$ (version 3.4.3, R Core Team, 2017), with a single pool plus constant model (Pendall et al., 2011) to estimate the size of the labile $\mathrm{C}$ pool $\left(C_{a}\right)$, the intrinsic decay constant of the labile pool $(k)$, and the intrinsic decay constant of the stable $\mathrm{C}$ pool $\left(Y_{0}\right)$ :

$\frac{\mathrm{d} C}{\mathrm{~d} T}=C_{a} k e^{-k t}+Y_{0}$.

\subsection{Data analysis}

Field soil respiration rates were analysed using a two-factor repeated measures ANOVA with warming and removal as the fixed factors. Since soil temperature $\left(T_{\mathrm{S}}\right)$ and SWC are known controllers of $R_{\mathrm{S}}$ and varied substantially over the year, we also analysed field $R_{\mathrm{S}}$ with a two-factor analysis of variance (ANOVA) with $T_{\mathrm{S}}$ and SWC and the interaction between $T_{\mathrm{S}}$ and SWC as covariates. Treatment means were calculated as least-squares means using the lsmeans package to account for the influences of covariates (Lenth, 2018). Treatment effects on SWC and $T_{\mathrm{S}}$ were analysed using a twofactor repeated measures ANOVA exactly as they were for $R_{\mathrm{S}}$. 
Because there was a significant influence of warming on $R_{\mathrm{S}}$, we created a separate model of the influence of SWC and $T_{\mathrm{S}}$ on in situ $R_{\mathrm{S}}$ for warmed and unwarmed plots. Since the respiration-temperature relationship is best described by an Arrhenius-type function (Fang and Moncrieff, 2001), we used multiple regression techniques to fit an exponential relationship to $R_{\mathrm{S}}$ and $\mathrm{SWC}, T_{\mathrm{S}}$, and the interaction between $T_{\mathrm{S}}$ and SWC. Such a non-linear relationship fitted the observed data far better than a linear model, as compared by the Akaike information criterion, which was corrected for a finite sample size.

Total cumulative $\mathrm{CO}_{2}$ emitted in laboratory incubations, $C_{a}, k$, and $Y_{0}$ for each season were compared using a three-factor analysis of variance ANOVA for both summer and winter soils with incubation temperature, warming, and species removal as fixed factors, including all interactions. Seasonal differences were also analysed using four-factor ANOVA, with season also included as a fixed factor along with warming effect, removal and incubation temperature.

All statistical analyses were carried out in $\mathrm{R}$ (version 3.4.3). Data were checked for heteroscedasticity and normality, and the required transformations were made using the Box-Cox power and logarithmic transformations. Significant treatment effects were further analysed using Tukey's Honest Significant Difference (HSD) post hoc comparisons.

\section{Results}

\subsection{In situ soil respiration}

\subsection{1 $\mathrm{CO}_{2}$ efflux}

Experimental warming drove a significant increase in soil respiration over the course of the year $\left(F_{1,12}=58.48\right.$; $P<0.001$; Table 1) but there was no significant influence of the species removal treatment, so neither the dominant nor random removal treatments were different to the untouched plots $\left(F_{2,12}=1.1 ; P=0.36\right)$, nor was there a warmingremoval interaction effect on $\mathrm{CO}_{2}$ efflux $\left(F_{2,12}=0.14\right.$; $P=0.87)$. As expected, time of year had a strong effect of $\mathrm{CO}_{2}$ efflux $\left(F_{6,12}=11.84 ; P<0.001\right)$, with the highest rates, $13.23 \pm 0.37 \mu \mathrm{mol} \mathrm{CO} \mathrm{m}^{-2} \mathrm{~s}^{-1}$ in summer, decreasing through to $1.4 \pm 0.06 \mu \mathrm{mol} \mathrm{CO} \mathrm{Cm}^{-2} \mathrm{~s}^{-1}$ in winter (Table 1). Despite the strong variation in $\mathrm{C}$ efflux rates across the year, there was no significant interaction between month and warming $\left(F_{5,12}=1.17 ; P=0.38\right)$, indicating that the warming effect was consistent across the year.

\subsubsection{Soil temperature}

Time of year had a strong impact on soil temperature $\left(F_{6,12}=27.61 ; P<0.001\right)$, which varied from $3.33 \pm 0.18^{\circ} \mathrm{C}$ to $18.89 \pm 0.14^{\circ} \mathrm{C}$ over the study period. Experimental warming had a significant impact on soil temperature, increasing soil temperature at $5 \mathrm{~cm}$ depth by $0.55^{\circ} \mathrm{C}$ on average
$\left(F_{1,12}=7.31 ; P=0.02\right)$. This impact was sustained over the year with no significant month-warming interaction $\left(F_{5,12}=\right.$ $0.88 ; P=0.52$ ), indicating that the warming chambers had a similar effect on soil temperature across the year. Neither removal treatment, i.e. neither dominant nor random biomass removal $\left(F_{2,12}=1.99 ; P=0.18\right)$, nor warming-removal interactions $\left(F_{2,12}=0.45 ; P=0.65\right)$ affected soil temperature. Thus, the warming treatment increased soil temperatures consistently over the year and across the species removal treatments.

\subsubsection{Soil water content}

Soil water content (SWC) also varied over the year $\left(F_{6,12}=\right.$ $6.21 ; P=0.003)$ reflecting precipitation patterns at Silver Plains (BOM, 2018). Over the course of the year, SWC ranged from $9.83 \pm 0.17 \%$ to $52 \pm 1.69 \%$, with moisture levels decreasing from winter 2017 through to autumn 2018, and then steeply increasing again in winter 2018 (Table 1). Experimental warming significantly decreased SWC throughout the year by $3 \%$ on average $(P<0.001)$, which is expected considering the drying effect of warming. However, the impact of warming on SWC depended upon the month, as indicated by a significant sampling month-warming effect $\left(F_{5,12}=6.09 ; P=0.005\right)$. Warming had the greatest effect on SWC in August 2017 and June 2018, when SWC was highest and soil temperature was lowest. SWC in these winter months was substantially higher than during the rest of the year, with SWC on average $34 \%$ and $58 \%$ higher in August and June, respectively, than the overall mean value $(21.3 \pm 0.5 \%)$. The proportional reduction in SWC due to warming in these months was nearly 2 times the yearly average. Otherwise, the warming effect was similar between sampling months. There was no significant influence of the removal treatment, i.e. neither the dominant nor the random removal treatment was different to the untouched plots $\left(F_{2,12}=0.23 ; P=0.8\right)$, nor was there a warming-removal interaction effect on SWC $\left(F_{2,12}=0.52 ; P=0.61\right)$, again indicating that plant species removal did not alter the influence of the warming treatment.

\subsubsection{Relationships between environmental factors and $\mathrm{CO}_{2}$ efflux}

Both soil temperature $\left(F_{1,33}=33.62 ; P<0.001\right)$ and SWC $\left(F_{1,33}=5.95 ; P=0.02\right)$ were strong controllers of soil $\mathrm{CO}_{2}$ efflux over the year at Silver Plains (Fig. 2). However, treatment effects on these abiotic factors alone were insufficient to explain the higher $\mathrm{C}$ efflux in warmed plots, as ANCOVA indicated that the warming treatment still induced significant increases in $\mathrm{CO}_{2}$ efflux when variation in soil $T$ and SWC were accounted for $\left(F_{1,33}=44.83 ; P<0.001\right)$. Thus, the warming treatment increased soil $\mathrm{CO}_{2}$ efflux independently of its effects on soil temperature and SWC (Fig. 2). Across the whole year, least-squares (LS) mean $\mathrm{CO}_{2}$ efflux rates for 
Table 1. The impact of experimental warming on soil $\mathrm{CO}_{2}$ efflux, soil temperature, and soil water content in the Silver Plains warming experiment from August 2017 to June 2018. Values shown are means with standard errors in parentheses $(n=20)$ Asterisks next to warmed means indicate significant differences $(P<0.05)$ between means of warmed and ambient plots within a month.

\begin{tabular}{llrrr}
\hline \multirow{2}{*}{ Month } & Treatment & $\begin{array}{r}\mathrm{CO}_{2} \text { efflux } \\
\left(\mu \mathrm{mol} \mathrm{CO}_{2} \mathrm{~m}^{-2} \mathrm{~s}^{-1}\right)\end{array}$ & $\begin{array}{r}\text { Soil temperature } \\
\left({ }^{\circ} \mathrm{C}\right)\end{array}$ & $\begin{array}{r}\text { SWC } \\
(\%)\end{array}$ \\
\hline \multirow{2}{*}{ August } & Ambient & $1.8(0.1)$ & $5.1(0.1)$ & $34.3(0.6)$ \\
& Warmed & $2.3(0.1)^{*}$ & $5.3(0.1)$ & $27.4(0.5)^{*}$ \\
\hline \multirow{2}{*}{ January } & Ambient & $8.0(0.3)$ & $16.0(0.3)$ & $19.8(1.0)$ \\
& Warmed & $12.2(0.4)^{*}$ & $16.9(0.3)$ & $16.5(0.7)^{*}$ \\
\hline \multirow{2}{*}{ February } & Warmed & $11.6(0.3)$ & $17.1(0.2)$ & $19.3(0.4)$ \\
& Ambient & $13.2(0.4)^{*}$ & $17.8(0.2)^{*}$ & $17.5(0.6)^{*}$ \\
\hline \multirow{2}{*}{ March } & Warmed & $7.6(0.2)$ & $18.9(0.1)$ & $13.3(0.2)$ \\
& Ambient & $12.9(0.5)^{*}$ & $18.8(0.1)$ & $12.6(0.3)^{*}$ \\
\hline \multirow{2}{*}{ April } & Warmed & $6.1(0.1)$ & $13.3(0.3)$ & $20.6(0.3)$ \\
& Ambient & $9.0(0.2)^{*}$ & $13.5(0.2)$ & $15.8(0.3)^{*}$ \\
\hline May & Warmed & $4.7(0.1)$ & $12.6(0.2)$ & $13.7(0.3)$ \\
& Ambient & $7.3(0.1)^{*}$ & $13.2(0.1)^{*}$ & $11.1(0.3)^{*}$ \\
\hline June & Warmed & $4.0(0.1)$ & $10.9(0.3)$ & $12.1(0.3)$ \\
& Ambient & $5.7(0.1)^{*}$ & $12.3(0.2)^{*}$ & $9.8(0.2)^{*}$ \\
\hline & Warmed & $1.4(0.1)$ & $3.3(0.2)$ & $52.0(1.7)$ \\
& $1.7(0.1)$ & $4.1(0.1)$ & $45.3(1.2)$ \\
\hline
\end{tabular}

ambient soils were $6.07(\mathrm{CI}=5.69,6.45) \mu \mathrm{mol} \mathrm{CO} 2 \mathrm{~m}^{-2} \mathrm{~s}^{-1}$ but $8.48 \mu \mathrm{mol} \mathrm{CO}_{2} \mathrm{~m}^{-2} \mathrm{~s}^{-1}(\mathrm{CI}=8.09,8.86)$ for warmed soils, amounting to a warming-induced increase of $28 \%$ at a common soil temperature and SWC. As $\mathrm{CO}_{2}$ efflux measurements spanned a large variation in both soil $T$ and SWC, it was possible to discern a trend whereby the stimulation of $\mathrm{C}$ efflux by warming became more pronounced as soil temperature increased (Fig. 2). Neither removal treatment $\left(F_{2,33}=0.89 ; P=0.42\right)$ nor a warming-removal interaction $\left(F_{2,33}=0.57 ; P=0.57\right)$ affected $\mathrm{CO}_{2}$ efflux, as indicated by ANCOVA.

\subsubsection{Models of $\mathrm{CO}_{2}$ efflux}

As ANCOVA indicated that soil $\mathrm{CO}_{2}$ efflux at Silver Plains was significantly influenced by soil temperature, SWC, and a strong warming effect, the relationship between these covariates and $\mathrm{CO}_{2}$ efflux could be estimated separately for ambient and warmed treatments. First, a general regression model of $\mathrm{CO}_{2}$ efflux was fit and selected using model selection based on Akaike Information Criterion with a correction for small sample sizes (AICc). The most parsimonious and accurate model was one that included soil temperature $\left(T_{\mathrm{S}}\right)$, $\mathrm{SWC}$, and a $\mathrm{SWC} \times T_{\mathrm{S}}$ interaction term (Int.term).

This model was then fit independently to ambient and warmed plots using the relative coefficient values, with $89 \%$ of the variance in $\mathrm{CO}_{2}$ efflux explained in warmed plots Eq. (2) and $82 \%$ in ambient plots Eq. (3).

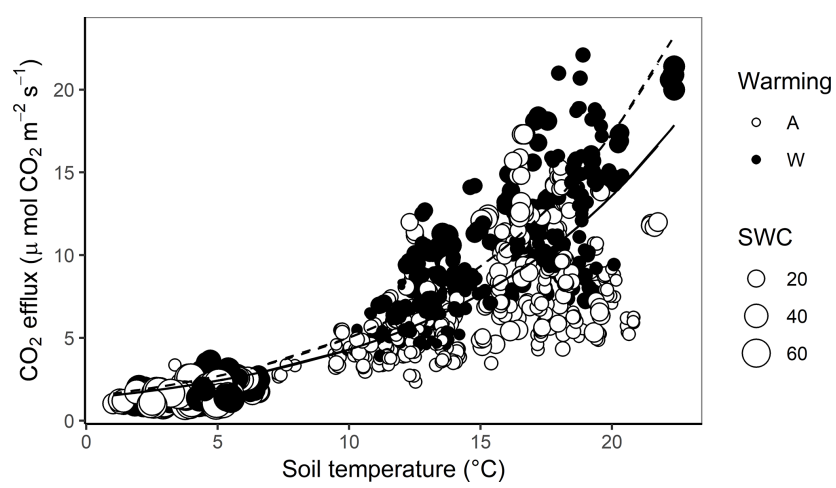

Figure 2. $\mathrm{CO}_{2}$ efflux as a function of soil temperature and soil water content for warmed (W) and ambient (A) plots at Silver Plains from August 2017 to June 2018. The size of each point represents SWC\%, with larger points corresponding to higher SWC. The regression lines indicate the relationship between $\mathrm{CO}_{2}$ efflux and soil temperature at median SWC in ambient plots (solid line) and warmed plots (dashed line).

$$
\begin{aligned}
& \mathrm{CO}_{2} \text { efflux } \\
& \quad=e^{\left(-0.8+0.359 \log (\mathrm{SWC})+0.115\left(T_{\mathrm{S}}\right)+0.003(\text { Int.term })\right)} \\
& \quad R^{2}=0.82 \\
& \mathrm{CO}_{2} \text { efflux }_{\text {warmed }} \\
& =e^{\left(-0.06+0.148 \log (\mathrm{SWC})+0.124\left(T_{\mathrm{S}}\right)+0.002(\text { Int.term })\right)} \\
& R^{2}=0.89
\end{aligned}
$$


Thus, it is possible to model $\mathrm{CO}_{2}$ efflux across a range of soil temperature and SWC values in both ambient unwarmed (Fig. 3a) and warmed conditions (Fig. 3b). From these plots, it is possible to determine that while the $\mathrm{CO}_{2}$ efflux rate increases more steeply with rising temperature in warmed plots than in unwarmed plots, the way in which it does so is also dependent upon the SWC (Fig. 3a and b). Thus, the impact of experimental warming on soil $\mathrm{CO}_{2}$ efflux was greatest in warm $\left(T_{\mathrm{S}}>15^{\circ} \mathrm{C}\right)$ and relatively dry conditions (SWC $<30 \%$; Fig. 4).

\subsection{Laboratory incubations}

\subsubsection{Total $\mathrm{C}$ mineralisation}

To determine whether experimental treatments altered potential microbial respiration, soil samples were collected in summer and winter for laboratory incubations. These incubations allowed the temperature sensitivity of soil respiration, the size of the labile $\mathrm{C}$ pool $\left(C_{a}\right)$ and its decay constant $(k)$ to be assessed, and the decay constant of the more resilient stable $\mathrm{C}$ pool $\left(Y_{0}\right)$ to be assessed under constant, optimal conditions. From soils collected in summer, the total amount of $\mathrm{C}$ mineralised increased substantially as an effect of incubation temperature; however, there were no effects of either the warming or removal treatments. On average, soil incubated at $17^{\circ} \mathrm{C}$ for 2 months emitted $48 \%$ more $\mathrm{C}$ than at $10^{\circ} \mathrm{C}$ and a further $22 \%$ at $25^{\circ} \mathrm{C}\left(F_{2,82}=80.9 ; P=<0.001\right.$; Fig. 5). From soils collected in winter, total $\mathrm{C}$ mineralised again only increased significantly as an effect of incubation temperature, with a $26 \%$ increase on average in $\mathrm{C}$ emitted at $17^{\circ} \mathrm{C}$ from $10^{\circ} \mathrm{C}$ and a further $27 \%$ increase at $25^{\circ} \mathrm{C}$ $\left(F_{2,112}=49.56 ; P<0.001\right.$; Fig. 5$)$. Just as with soil collected in summer, there were no treatment effects on the total amount of $\mathrm{C}$ mineralised from winter soils $\left(F_{1,112}=0.04\right.$; $P=0.84)$. Between seasons, winter soils emitted on average $24 \%$ less $C$ than summer soils $\left(F_{1,196}=33.66 ; P<0.001\right)$, most likely because of the higher SWC used for the winter soils, and neither the removal treatment, i.e. neither dominant nor random biomass removal $\left(F_{2,196}=0.67 ; P=0.51\right)$, nor warming significantly affected total $\mathrm{C}$ mineralised overall $\left(F_{1,196}=0.01 ; P=0.92\right)$.

\subsubsection{Labile C}

In summer soil, incubation temperature significantly increased the size of $C_{a}$ on average by $50 \%$ from $10^{\circ} \mathrm{C}$ to $17^{\circ} \mathrm{C}$ and by a further $18 \%$ at $25^{\circ} \mathrm{C}(P<0.001)$ (Fig. 6a). There were no treatment effects on the size of $C_{a}$. Winter soil incubations reflect similar results to those for summer soils, with a $27 \%$ increase in $C_{a}$ pool size from 10 to $17^{\circ} \mathrm{C}$ and a further $27 \%$ increase to $25^{\circ} \mathrm{C}(P=0.001)$. As with summer soil, there were no treatment effects. Overall, season had no effect on $C_{a}$; however, incubation temperature increased
$C_{a}$ across the two seasons by $36 \%$ from 10 to $17^{\circ} \mathrm{C}$ and a further $24 \%$ at $25^{\circ} \mathrm{C}(P<0.001)$.

The intrinsic decay constant of the labile pool $(k)$ in summer soil was not affected by incubation temperature $\left(F_{2,82}=\right.$ $0.39 ; P=0.68)$, warming $\left(F_{1,82}=0.06 ; P=0.8\right)$, or the removal treatments, i.e. neither dominant nor random biomass removal $\left(F_{2,82}=0.31 ; P=0.73\right)$. However, it was significantly influenced by an interaction between warming and species removal $\left(F_{2,82}=3.14 ; P=0.05\right)$ (Fig. $\left.6 \mathrm{c}\right)$. In ambient plots, removing the dominant species tended to increase $k$; however, in warmed plots, the opposite occurred. Post hoc analysis revealed the greatest differences in $k$ were observed between (i) warmed-no removal and warmeddominant removal plots and (ii) warmed-dominant removal and ambient-dominant removal plots. In winter, there were no treatment or incubation temperature effects on $k$; however, $k$ was on average $42 \%$ greater in summer $\left(F_{1,196}=201.09\right.$; $P<0.001)$.

\subsubsection{Intrinsic decay constant of the stable $\mathrm{C}$ pool}

From summer soil, the size of the stable $\mathrm{C}$ pool $\left(Y_{0}\right)$ also increased significantly $\left(F_{2,82}=78.01 ; P<2^{-16}\right)$ as a function of incubation temperature with an average increase of $47 \%$ from 10 to $17^{\circ} \mathrm{C}$ and a further $20 \%$ at $25^{\circ} \mathrm{C}$ (Fig. $6 \mathrm{c}$ ). There were no treatment effects on the $Y_{0}$ of summer soil. For winter soils, responses to treatments were similar to those of summer soils. There were no treatment effects, but incubation temperature increased $Y_{0}$ by $27 \%$ on average from 10 to $17^{\circ} \mathrm{C}$ and a further $28 \%$ at $25^{\circ} \mathrm{C}\left(F_{2,112}=45.9\right.$; $P<0)$. Overall $Y_{0}$ was $39 \%$ higher in summer than in winter $\left(F_{1,196}=137.61 ; P<0.001\right)$, and incubation temperature also significantly increased $Y_{0}$ overall, with a $38 \%$ increase from 10 to $17^{\circ} \mathrm{C}$ on average and a further $23 \%$ at $25^{\circ} \mathrm{C}$ $\left(F_{1,196}=107.28 ; P<0.001\right)$; however, there were no treatment effects.

\subsubsection{Proportion of total $\mathrm{C}$ that was labile}

From summer soil, the proportion of total $\mathrm{C}$ that was from $C_{a}$ was only affected by incubation temperature with a $49 \%$ increase on average from 10 to $17^{\circ} \mathrm{C}$ and a further $22 \%$ increase when incubated at $25^{\circ} \mathrm{C}\left(F_{2,82}=77.73 ; P<0.001\right.$; Fig. 6d). There were no treatment effects. Similarly, in winter, the proportion of total $\mathrm{C}$ that was $C_{a}$ increased only as a function of increasing incubation temperature, with on average a $24 \%$ increase from 10 to $17^{\circ} \mathrm{C}$ and a further $27 \%$ at $25^{\circ} \mathrm{C}\left(F_{2,112}=22.19 ; P<0.001\right)$. Overall, the proportion of total C that was $C_{a}$, increased substantially as a function of incubation temperature $\left(F_{2,196}=67.94 ; P<0.001\right)$ with a $35 \%$ increase from 10 to $17^{\circ} \mathrm{C}$, and a further $25 \%$ increase at $25^{\circ} \mathrm{C}$, however there were no overall treatment effects. 

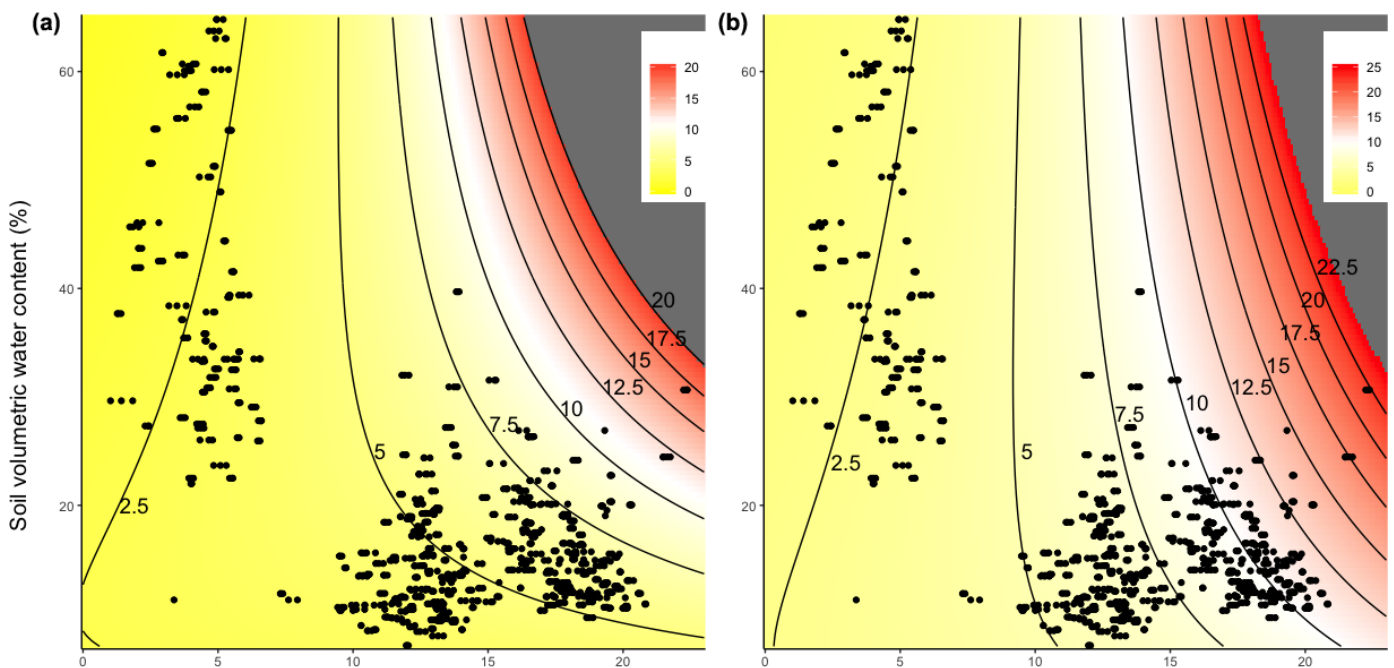

Soil temperature $\left({ }^{\circ} \mathrm{C}\right)$

Figure 3. $\mathrm{CO}_{2}$ efflux $\left(\mu \mathrm{mol} \mathrm{CO} \mathrm{CO}^{-2} \mathrm{~s}^{-1}\right)$ modelled as a function of soil temperature and $\mathrm{SWC}$ in (a) ambient plots and (b) warmed plots. Colour indicates predicted $\mathrm{CO}_{2}$ efflux values, and field observations are shown as individual points. Regions beyond the observed range of $\mathrm{CO}_{2}$ efflux rates are shown in grey.

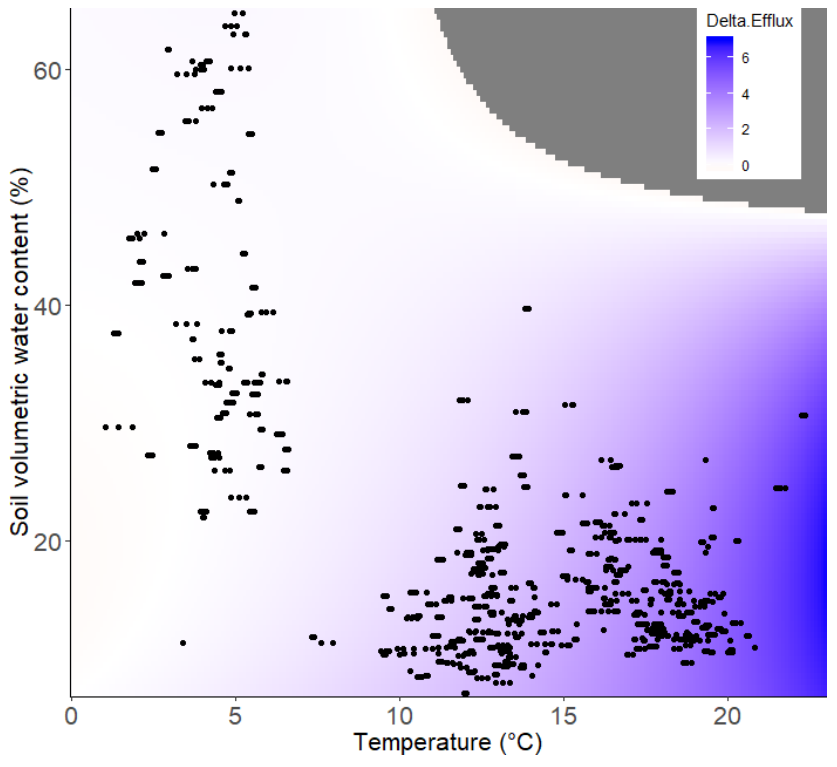

Figure 4. Delta $\mathrm{CO}_{2}$ efflux $\left(\mu \mathrm{molCO} \mathrm{Cm}^{-2} \mathrm{~s}^{-1}\right)$. The amount of extra $\mathrm{CO}_{2}$ that is likely to be released due to warming as a function of soil temperature $\left({ }^{\circ} \mathrm{C}\right)$ and $\operatorname{SWC}(\%)$. Data points represent actual measurements, and colour indicates predicted $\mathrm{CO}_{2}$ efflux. Points on the contour graphs are field observations and regions beyond field observations, and thus where $\mathrm{CO}_{2}$ cannot be predicted, are greyed out.

\subsection{Total soil C content}

Overall, irrespective of removal treatment, total soil $\mathrm{C} \%$ averaged $19.2 \pm 0.4(P<0.001)$. C\% was $18.7 \pm 0.7$ and

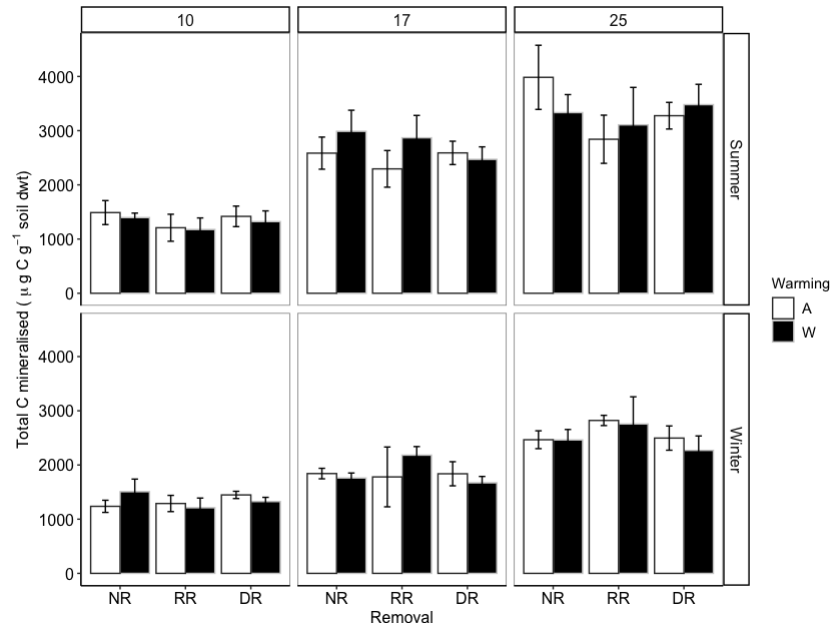

Figure 5. Total $\mathrm{C}$ mineralised in summer and winter from soils in no removal (NR), random removal (RR), and dominant removal (DR) plots at incubation temperatures of 10,17 , and $25^{\circ} \mathrm{C}$ for warmed (W) and ambient (A) treatments.

$19.7 \pm 0.6$ in ambient and warmed soils, respectively; however, there were no significant treatment effects.

All incubation results were also analysed per gram of soil $\mathrm{C}$, but results were essentially identical to those expressed per gram of soil dry weight given above.

\section{Discussion}

The main aim of this study was to investigate whether warming increases $R_{\mathrm{S}}$ in situ and whether any observed treatment 
(a)

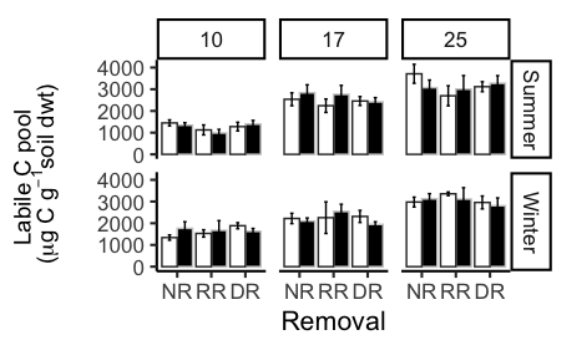

(c)

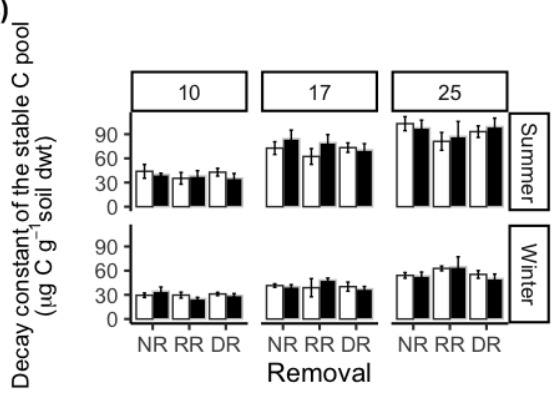

(b)

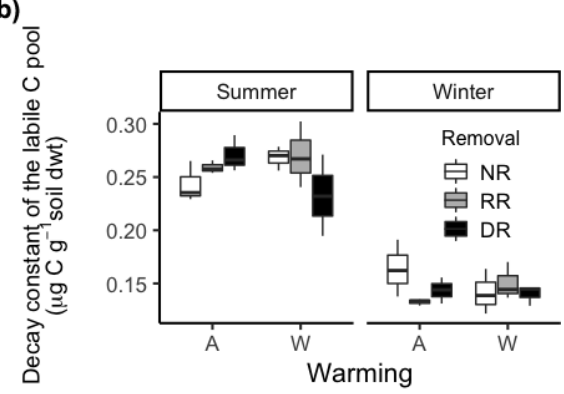

(d)

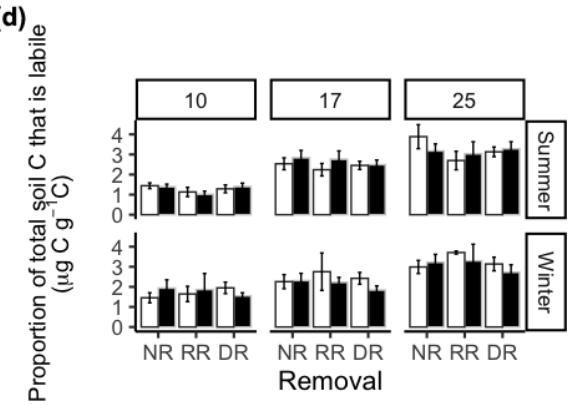

Figure 6. (a) Labile $\mathrm{C}$ pool size $\left(C_{a}\right)$ in summer and winter soils in no removal (NR), random removal (RR), and dominant removal (DR) plots at incubation temperature: 10,17 , and $25^{\circ} \mathrm{C}$ for warmed (black) and ambient (white) treatments. (b) Intrinsic decay constant of the labile $\mathrm{C}$ pool $(k)$ for both summer and winter soils in no removal (NR), random removal (RR), and dominant removal (DR) plots at incubation temperature: 10,17 , and $25^{\circ} \mathrm{C}$ for warmed (black) and ambient (white) treatments. (c) The intrinsic decay constant of the stable $\mathrm{C}$ pool ( $\left.Y_{0}\right)$ in summer and winter soils in no removal (NR), random removal (RR), and dominant removal (DR) plots at incubation temperature: 10, 17, and $25^{\circ} \mathrm{C}$ for warmed (black) and ambient (white) treatments. (d) Proportion of total $\mathrm{C}$ that is from the labile $\mathrm{C}$ pool $\left(C_{a}\right)$ in both summer and winter soils in no removal (NR), random removal (RR), and dominant removal (DR) plots at incubation temperature: 10,17 , and $25^{\circ} \mathrm{C}$ for warmed (black) and ambient (white) treatments.

effects were due to an increased ability of the soil microbial community to mineralise SOC. Additionally, we investigated whether manipulating plant community composition affected the $R_{\mathrm{S}}$ response to warming. Results demonstrated strong warming-related increases in $R_{\mathrm{S}}$ in situ; however, there were no warming effects on microbial respiratory potential. Additionally, the warming treatment increased soil temperature and decreased soil water content significantly in situ; however, the warming effect on $R_{\mathrm{S}}$ was greater than expected considering the impact it had on these abiotic factors. Thus, warming increased $R_{\mathrm{S}}$ more than simply by increasing soil temperature and reducing soil water content. Manipulating the plant community by removing the dominant species or removing biomass had no impact on $R_{\mathrm{S}}$, nor did these treatments influence the impact of warming on $R_{\mathrm{S}}$. This suggests that the warming-induced increase in $R_{\mathrm{S}}$ was independent of any influences on plant community composition. Similarly, removal treatments did not affect microbial respiratory potential; however, there was a complex warming and removal interaction that influenced the decay constant of the soil labile $\mathrm{C}$ pool $(k)$. Overall, the results from this study suggest that as there was no change in microbial respiratory potential, the observed increase in soil respiration in situ was largely an effect of altered plant activity in warmed plots.

\subsection{Possible mechanisms leading to the warming-induced increase in soil respiration}

Warming increased $R_{\mathrm{S}}$ in situ over the course of the sampling period from November 2017 to June 2018. This increase in $\mathrm{CO}_{2}$ efflux observed from soils in situ, which encompasses the response of microbial (heterotrophic) respiration, as well as contributions from plant root and minor contributions from shoot (autotrophic) respiration, amounted to an average increase in soil $\mathrm{C}$ efflux of $28 \%$. The observed increase of $R_{\mathrm{S}}$ in response to warming is in line with multiple other studies, although most of these focus on soils in the low to middle range of soil $\mathrm{C}$ stocks and in Northern Hemisphere locations (Lu et al., 2013; van Gestel et al., 2018). There are five possible mechanisms whereby $R_{\mathrm{S}}$ could have increased by warming: (1) increased temperature sensitivity of $R_{\mathrm{S}},(2)$ alteration of microbial community composition and function, (3) influence through change in plant community composition, (4) enhanced substrate supply through SOM, and (5) plant-induced alteration to soil microhabitat. The substantial $R_{\mathrm{S}}$ response to warming could be due to one or a combination of these processes and determining which were likely to be involved has significant ramifications for our ability to predict future soil $\mathrm{C}$ dynamics. 


\subsubsection{Increased temperature sensitivity of $\boldsymbol{R}_{\mathrm{S}}$}

One of the proposed mechanisms behind the increased $R_{\mathrm{S}}$ response to warming and subsequent loss of soil $\mathrm{C}$ stores is an increase in the temperature sensitivity of $R_{\mathrm{S}}$, i.e. increased decomposition of SOM (Kirschbaum, 1995). This response, mainly attributed to an increase in enzyme kinetics with temperature, is linked strongly to substrate availability (Davidson and Janssens, 2006). At Silver Plains, the overall significant increase in $R_{\mathrm{S}}$ rates from warmed plots in situ implied that the temperature sensitivity of $R_{\mathrm{S}}$ was higher under warming. The highest $R_{\mathrm{S}}$ rates were recorded during the growing season in spring and summer, suggesting primary productivity, microbial activity, and environmental factors such as precipitation are likely to substantially influence respiration rates (Almagro et al., 2009). However, despite the strong dependence of $R_{\mathrm{S}}$ on soil water content and soil temperature, warmed plots had higher rates of $\mathrm{C}$ efflux from the soil under particular combinations of soil temperature and moisture (Sect. 3.1.5, Fig. 3). The restrictive effect of high soil water content and low soil temperature on $R_{\mathrm{S}}$ observed in this study is widely documented and, due to the creation of anoxic conditions, limits microbial access to substrate (Schimel et al., 1994; Syed et al., 2006; Sierra et al., 2015). Hence, the observed effect of soil water content and soil temperature on $R_{\mathrm{S}}$ was anticipated; however, the degree to which warming enhanced the response of $R_{\mathrm{S}}$ to temperature was greater than expected. This observation could be explained by the greater effect of warming on air temperature than soil temperature at $5 \mathrm{~cm}$; thus, considering most soil microbial activity occurs in the uppermost few centimetres, it is possible the most biologically active soil layer was warmed more than the amount measured, partially accounting for the large increase in $R_{\mathrm{S}}$. However, the warming-depth profile at Silver Plains is unknown and also largely unreported from other warming experiments, except at greater depths (e.g. 0$5 \mathrm{~cm}$ versus $5-15 \mathrm{~cm}$; Hollister et al., 2006). Clearly, the influence of warming treatments on the soil temperature-depth profile is an area that requires further investigation. Interestingly, our results show that the degree of stimulation by warming increased as soil temperature increased, i.e., there was a greater warming-induced stimulation of $\mathrm{C}$ efflux when soil was warm than when it was cold (Fig. 2). This contrasts with previous findings that indicate a greater warming effect on $R_{\mathrm{S}}$ at lower temperatures (Wang et al., 2014).

The large apparent increase in $R_{\mathrm{S}}$ observed in situ implied that warming possibly triggered an increase in microbial respiratory potential. Partitioning of $R_{\mathrm{S}}$ in incubation experiments allows the response of microbial respiration to warming to be observed under optimal conditions, controlling for soil water content and soil temperature. In stark contrast to the in situ observations, soil incubations revealed no differences in the temperature sensitivity of microbial respiration between warmed and ambient soil. There were no differences among treatments in the total $\mathrm{C}$ mineralisation rate measured under laboratory conditions, which would indicate that the ability of the soil microbial community to mineralise soil C was unchanged. This lack of any treatment effect was similar in winter- and summer-collected soils, even though there was a strong seasonal effect on the $\mathrm{CO}_{2}$ respiration rate in incubated soils. Winter soils emitted significantly less $\mathrm{CO}_{2}$ than soils collected at the end of summer, a response attributed to decreased access to substrate as an effect of limited enzyme activity in cold temperatures (Suseela et al., 2012). Additionally, despite claims that the warming-induced increase in $R_{\mathrm{S}}$ is due to a strong, positive relationship between the average turnover time of labile $\mathrm{C}$ pools and mean annual air temperature (Trumbore et al., 1996), there was no difference in the size of the respired labile $\mathrm{C}$ pool $\left(C_{a}\right)$ between warmed and ambient soils or between seasons. Therefore, this suggests that the warming treatment did not increase the temperature sensitivity of labile $\mathrm{C}$ decomposition. Additionally, there were no warming or removal treatment effects on the decay constant of the stable $\mathrm{C}$ pool $\left(Y_{0}\right)$ calculated from $\mathrm{CO}_{2}$ emission rates late in the incubation period. This implies that stable $\mathrm{C}$, which is chemically and physically protected (Schlesinger, 1997), was not sensitive to warming, a response that contrasts with results obtained elsewhere (Leifeld and Fuhrer, 2005; Hartley and Ineson, 2008). Thus, lack of a warming effect indicates that warming-induced increases in labile or stable $\mathrm{C}$ temperature sensitivity are not driving the $R_{\mathrm{S}}$ response to warming observed in situ.

Essentially, the incubation studies revealed that 4 years of experimental warming had not altered either the potential for microbial respiration or its inherent temperature response, as soils incubated at the same temperature respired more or less at the same rate, regardless of whether they were collected from warmed or ambient plots. These results indicate that the warming-induced stimulation of $R_{\mathrm{S}}$ in situ was not due to changes in the inherent temperature response of microbial respiration. Considering the soil incubation experiment decoupled microbial respiration from plant activity and $\mathrm{C}$ inputs in particular, the lack of a warming treatment effect on $\mathrm{C}$ emissions in the incubation experiments is evidence that plants play a large role in the respiration response.

\subsubsection{Alteration of microbial community composition and function}

The role of microbial community composition and function in the respiration response to warming is complex as it encompasses multiple possible factors that could lead to changes in respiration rates (Bargett and Caruso, 2020; Karhu et al., 2014). These factors include changes in individual microbial physiology, whereby temperature affects the rate at which microbes can take up and metabolise substrate (Hopkins et al., 2014), genetic changes within species that indicate possible adaption to specific environmental conditions (Karhu et al., 2014), competition between species (Sheik et al., 2011), and changes in community composition to support 
taxa that thrive in warmer or drought-prone conditions (Bardgett and Caruso, 2020). From the $R_{\mathrm{S}}$ response observed in situ, a shift in microbial community composition and function seems to be a plausible driving factor. However, laboratory incubations of soil indicated the temperature response of respiratory potential in this study did not differ due to an increase in temperature in the warming treatment. If there were changes to the microbial community, they did not appear to have a role in altering the response of respiration to warming, implying the $R_{\mathrm{S}}$ response was not due to a shift in microbial community and function.

\subsubsection{Influence through change in plant species community composition}

Plant community compositional change drives ecosystem responses to global changes, particularly when it involves shifts in the dominance or abundance of plant functional types (Bret-Harte et al., 2008). This is particularly true with $R_{\mathrm{S}}$ and global warming, as warming-related changes in plant functional types, and hence the resources they input to the soil, are highly likely to occur (Saleska et al., 2002). By investigating the effects of dominant species removal, random biomass removal, and warming on the response of respiration, there is scope to gain insight into future ecosystem dynamics under a changing climate. Removal of a dominant species from an ecosystem has promoted species diversity and altered ecosystem function, implying dominant species reduce the establishment of other species (Wardle et al., 1999). Metcalfe et al. (2011) highlight the significant role that functional traits of the dominant species hold on many soil processes, including decomposition and respiration, and hence one would expect to observe these effects in this study. Plants modify local soil conditions through root exudations of hormones, sugars, phenolics, and amino acids, essentially structuring the rhizosphere microbial community composition. This means that changes in plant community composition have the potential to affect $R_{\mathrm{S}}$ and thus ecosystem functioning (Van Nuland et al., 2016), and hence provide the motive to investigate how $R_{\mathrm{S}}$ responds to the combination of warming and manipulated plant community composition. Results from Silver Plains demonstrate that neither removal of the dominant plant species nor random removal of biomass had any effect on $R_{\mathrm{S}}$ or the temperature response of $R_{\mathrm{S}}$ in situ, and very little effect on microbial respiratory potential. This suggests that, in line with previous studies, temperature had greater control on $R_{\mathrm{S}}$ than variation in plant community composition (Duval and Radu, 2018).

Multidimensional scaling analysis of plant community composition indicated that the removal of the dominant species did tend to shift community composition, but this change was not substantial in comparison to the natural variation in community composition within the control plots (Fig. S1 in the Supplement). The plant community composition in plots subjected to random biomass removal was similar to that of control plots. Furthermore, the removal of the dominant species did not appear to cause any functional shift within this species-rich community, suggesting it may have been replaced by a functionally similar species or that there was a compensatory response by functionally different species (Bret-Harte et al., 2008). Thus, the removal treatments had relatively modest influences on the plant community composition and function, potentially explaining why $R_{\mathrm{S}}$ was similarly unresponsive to the treatments. Nevertheless, the plant community composition did differ considerably among plots across the experiment (Fig. S1). Differences in plant chemistry, morphology, and physiology affect the quantity and quality of root and leaf litter, leading to changes in SOM decomposition rates and shifts in microbial respiratory potential and community structure (Van $\mathrm{Nu}$ land et al., 2016). However, the consistent response of $R_{\mathrm{S}}$ in situ to the warming treatment indicates that warming effects were similar across the variety of plant community composition within this ecosystem.

Despite the absence of an effect on $R_{\mathrm{S}}$ in situ from manipulating species composition, microbial respiration dynamics indicated that warming and biomass removal (both random and dominant removal treatments) reduced the intrinsic decay constant of the labile $\mathrm{C}$ pool $(k)$ in summer soil. Interestingly, biomass removal had the opposite effect in ambient plots. In a previous clipping experiment, which is representative of biomass removal, a decrease in $R_{\mathrm{S}}$ due to clipping was explained as relocation of assimilates to shoots, reduction in the supply of photosynthates to roots, and thus decreased root respiration (Zhou et al., 2010). Hence there is likely to be less available substrate under warming and biomass removal scenarios, and $k$ is therefore lower. Considering this, the interactive effect of warming and biomass removal on $k$ is complex and requires further investigation to explore the mechanistic basis behind the response. The absence of an influence on $R_{\mathrm{S}}$ through variation in plant community composition suggests this mechanism is not driving the warming-induced $R_{\mathrm{S}}$ response to warming.

\subsubsection{Enhanced substrate supply}

\section{SOM}

As SOM forms mainly from plant litter, warming-related increases in both above- and below-ground primary productivity suggest supply of SOM will be greater under warming (Rustad et al., 2001; Lin et al., 2010; Wu et al., 2011), at least in systems that are not water limited. Additionally, experimental warming often increases leaf drop, root turnover, and the subsequent decomposition of leaf and root litter (Lu et al., 2013), with the combined effects of warming and higher $C$ inputs on respiration rates reported to be greater than the impact of either factor in isolation (Hopkins et al., 2014). Root and leaf litter have fast turnover times, implying they represent a major source of $\mathrm{C}$ for microbial decomposition. There- 
fore, an increase in the input of easily degradable $\mathrm{C}$ would both promote microbial activity (Wan et al., 2005; Hogberg and Read, 2006), potentially stimulating soil C efflux, as well as increase formation of stable SOM through microbial decomposition products (Sokol et al., 2019). Considering this, an increase in substrate supply seems like a conceivable explanation for the increase in $R_{\mathrm{S}}$ observed in situ. However, incubation experiments indicated no influence of warming on the total amount of $\mathrm{C}$ between warmed and ambient plots or on the size of the labile pool $\left(C_{a}\right)$ or total $C$ respired. This indicates that substrate supply and availability from plant biomass is similar in warmed and ambient plots. Previous investigations suggest that despite warming-related increases in litter quantity, enhanced respiration due to increased labile $\mathrm{C}$ concentration in soils is likely to offset additional $\mathrm{C}$ inputs (Lu et al., 2013), meaning changes to both inputs and losses of soil $\mathrm{C}$ could balance each other. Interestingly, neither in situ $R_{\mathrm{S}}$ nor total soil C or $C_{a}$ was affected by plant community composition manipulations, suggesting substrate supply and availability was similar regardless of warming and removal treatments. This result contrasts with those from previous clipping experiments that demonstrated that biomass removal limits substrate supply (Wan and Luo, 2003; Xue et al., 2016). Overall this suggests that increased substrate supply through SOM is not a driving mechanism behind the warming-induced increase in $R_{\mathrm{S}}$ observed in situ, although specific tests of this mechanism, such as through the use of stable isotope tracing, would be required to be confident.

\subsubsection{Plant-induced alteration to soil microhabitat}

The final mechanism that could be driving the warminginduced increases in $R_{\mathrm{S}}$ are plant-induced alterations to the soil microhabitat. In this study, as in most, soil for incubations was not analysed as intact soil cores, rather it was sieved and homogenised, altering the microhabitat conditions. This is potentially problematic, as it is assuming that rhizosphere processes, including contributions from mycorrhizal fungi, are not influencing the overall $R_{\mathrm{S}}$ response. Previous studies have demonstrated the important role roots play in stabilising SOM (Hinsinger et al., 2009), with disturbed soils having a lower capacity to protect SOM due to mechanical disruption of macroaggregates, and hence $\mathrm{C}$ is more readily decomposed by microorganisms (Beare et al., 1994). Many, and potentially all, of the plant species at the site have associations with arbuscular mycorrhizae, which are known to increase SOM formation both directly as well as through their influence on soil aggregation (Rillig et al., 2001). Thus, our incubations would have removed this important contribution, reducing SOM formation and potentially increasing $\mathrm{C}$ mineralisation rates. Additionally, macrofauna such as earthworms and nematodes play an important role in the early stages of SOM decomposition (Wardle et al., 2004), and therefore the absence of these species from the incubations could also have influenced the rates of $\mathrm{C}$ efflux. Considering this, it is possi- ble that through homogenisation of soil in incubation studies, soil $\mathrm{C}$ dynamics and decomposition rates are confounded by disturbances to the soil microhabitat.

\subsection{Implications}

Large $\mathrm{C}$ stocks within this type of peaty habitat are important for the global $\mathrm{C}$ cycle, thus understanding potential losses are immensely important for the global $\mathrm{C}$ budget. Previous studies on the response of $R_{\mathrm{S}}$ to warming have been largely centred around Northern Hemisphere sites, and with that there has been large unexplained variability in the response (van Gestel et al., 2018). This implies that the mechanisms behind the $R_{\mathrm{S}}$ response to warming are poorly characterised. Our results indicate that warming-related increases in $\mathrm{CO}_{2}$ efflux from C-rich soils in grassy peatlands are expected in the future; however, microbial respiratory potential is not the driving factor, and thus there is a strong link to plant activity and $\mathrm{C}$ inputs. Moreover, the results indicate that the impact of warming on soil $\mathrm{CO}_{2}$ efflux is strongly dependent upon both soil temperature and moisture conditions, improving the confidence that current and future soil $\mathrm{CO}_{2}$ efflux can be modelled from these variables. However, the lack of observations in certain combinations of soil temperature and moisture means that predictions using the models presented here should be limited to the observed range. Future work should test the generality of these models in previously unobserved combinations of soil moisture and temperature.

Predictions regarding future climate conditions require a more comprehensive mechanistic understanding of temperature and decomposition relationships, especially considering the global variation in these relationships. Further investigation into the role of inputs is required, as warming could be driving increases in inputs, thereby balancing the accelerated $\mathrm{C}$ efflux and preventing net loss of $\mathrm{C}$ from soils. Alternatively, warming could lead to depletion of huge stores of C. This effect is no doubt subject to great variation depending on the ecosystem and hence the necessity to examine the response, accounting for heterogeneity in soil and vegetation types worldwide. Most importantly, this study revealed that $\mathrm{C}$ inputs through root exudates and root respiration were the two mechanisms most likely to be driving the $R_{\mathrm{S}}$ response to warming. Thus, more research into the influence of root exudates and root respiration on $R_{\mathrm{S}}$, particularly under warming, will provide a more comprehensive insight into the $R_{\mathrm{S}}$ response. Ultimately, thorough investigations into the whole ecosystem $\mathrm{C}$ exchange are required to advance the understanding of how warming will affect rates of inputs and outputs.

The increase in $R_{\mathrm{S}}$ in response to warming observed here is in line with previous experimental warming studies, although few have been conducted in C-rich soils. Thus, the results from this study contribute directly to a field of knowledge that is currently under-represented. Despite a strong warming effect, there appear to be no significant effects of 
plant community manipulation, suggesting that warming exerts more of an influence on $\mathrm{CO}_{2}$ efflux from soils than differences in plant communities. Additionally, results suggest that the microbial respiratory potential in this system is not altered by experimental warming and hence cannot be decoupled from plant activity if we are to enhance our ability to predict $\mathrm{C}$ cycling dynamics in a warmer climate. Current findings suggest warming is likely to trigger a positive feedback cycle whereby increases in global temperatures will enhance $\mathrm{CO}_{2}$ efflux from soils, subsequently warming the Earth further. As the huge $\mathrm{C}$ stocks in the soil have the potential to either amplify or attenuate global warming, the impacts of climate change on soil $\mathrm{C}$ dynamics require urgent investigation. A more comprehensive representation of ecosystem $\mathrm{C}$ exchange is needed, as well as the mechanisms involved, if we want to decrease $\mathrm{CO}_{2}$ efflux from soils and ensure these huge $\mathrm{C}$ sinks are stabilised or potentially even increased, such that the biosphere can sequester more atmospheric $\mathrm{CO}_{2}$ and help to stabilise the climate.

Data availability. Data can be accessed from the corresponding author upon request.

Supplement. The supplement related to this article is available online at: https://doi.org/10.5194/bg-17-4405-2020-supplement.

Author contributions. $\mathrm{MN}$ and $\mathrm{MJH}$ were responsible for conceptualisation and project administration. MN performed data acquisition and curation, formal analysis, and writing. MJH developed the methodology and provided supervision.

Competing interests. The authors declare that they have no conflict of interest.

Acknowledgements. We would like to thank Meagan Porter and Rose Brinkhoff for their help in setting up the experiment and the Tasmanian Land Conservancy for giving their permission to use the land for the experiment. This research did not receive any specific grant from funding agencies in the public, commercial, or not-forprofit sectors.

Review statement. This paper was edited by Jens-Arne Subke and reviewed by two anonymous referees.

\section{References}

Almagro, M., López, J., Querejeta, J. I., and Martínez-Mena, M.: Temperature dependence of soil $\mathrm{CO}_{2}$ efflux is strongly modulated by seasonal patterns of moisture availability in a Mediterranean ecosystem, Soil Biol. Biochem., 41, 594-605, https://doi.org/10.1016/j.soilbio.2008.12.021, 2009.

Bardgett, R. D. and Caruso, T.: Soil microbial community responses to climate extremes: resistance, resilience and transitions to alternative states, Philos. T. R. Soc. B, 375, 20190112, https://doi.org/10.1098/rstb.2019.0112, 2020.

Beare, M. H., Hendrix, P. F., Cabrera, M. L., and Coleman, D. C.: Aggregate-protected and unprotected organic matter pools in conventional- and notillage soils, Soil Sci. Soc. Am. J., 58, 787-795, https://doi.org/10.2136/sssaj1994.03615995005800030021x, 1994.

Bengtson, P., Barker, J., and Grayston, S. J.: Evidence of a strong coupling between root exudation, $\mathrm{C}$ and $\mathrm{N}$ availability, and stimulated SOM decomposition caused by rhizosphere priming effects, Ecol. Evol., 2, 1843-1852, https://doi.org/10.1002/ece3.311, 2012.

Bond-Lamberty, B. and Thomson, A.: Temperature-associated increases in the global soil respiration record, Nature, 464, 579582, https://doi.org/10.1038/nature08930, 2010.

Bond-Lamberty, B., Bailey, V. L., Chen, M., Gough, C. M., and Vargas, R.: Globally rising soil heterotrophic respiration over recent decades, Nature, 560, 80-83, https://doi.org/10.1038/s41586018-0358-x, 2018.

Boone, R. D., Nadelhoffer, K. J., Canary, J. D., and Kaye, J. P.: Roots exert a strong influence on the temperature sensitivity of soil respiration, Nature, 396, 570-572, https://doi.org/10.1038/25119, 1998.

Bracho, R., Natali, S., Pegoraro, E., Crummer, K. G., Schädel, C., Celis, G., Hale, L., Wu, L., Yin, H., Tiedje, J. M., Konstantinidis, K. T., Luo, Y., Zhou, J., and Schuur, E. A. G.: Temperature sensitivity of organic matter decomposition of permafrost-region soils during laboratory incubations, Soil Biol. Biochem., 97, 114, https://doi.org/10.1016/j.soilbio.2016.02.008, 2016.

Bradford, M. A., Davies, C. A., Frey, S. D., Maddox, T. R., Melillo, J. M., Mohan, J. E., Reynolds, J. F., Treseder, K. K., and Wallenstein, M. D.: Thermal adaptation of soil microbial respiration to elevated temperature, Ecol. Lett., 11, 1316-1327, https://doi.org/10.1111/j.1461-0248.2008.01251.x, 2008.

Bret-Harte, M. S., Mack, M. C., Goldsmith, G. R., Sloan, D. B., Demarco, J., Shaver, G. R., Ray, P. M., Biesinger, Z., and Chapin, F. S.: Plant functional types do not predict biomass responses to removal and fertilization in Alaskan tussock tundra, J. Ecol., 96, 713-726, https://doi.org/10.1111/j.1365-2745.2008.01378.x, 2008.

Bridgham, S. D., Pastor, J., Dewey, B., Weltzin, J. F., and Updegraff, K.: Rapid carbon response of peatlands to climate change, Ecology, 89, 3041-3048, https://doi.org/10.1890/08-0279.1, 2008.

Cai, T., Flanagan, L. B., and Syed, K. H.: Warmer and drier conditions stimulate respiration more than photosynthesis in a boreal peatland ecosystem: analysis of automatic chambers and eddy covariance measurements, Plant Cell Environ., 33, 394 407, https://doi.org/10.1111/j.1365-3040.2009.02089.x, 2010.

Canadell, J. G., Kirschbaum, M. U. F., Kurz, W. A., Sanz, M.-J., Schlamadinger, B., and Yamagata, Y.: Factoring 
out natural and indirect human effects on terrestrial carbon sources and sinks, Environ. Sci. Policy, 10, 370-384, https://doi.org/10.1016/j.envsci.2007.01.009, 2007.

Carey, J. C., Tang, J., Templer, P. H., Kroeger, K. D., Crowther, T. W., Burton, A. J., Dukes, J. S., Emmett, B., Frey, S. D., Heskel, M. A., Jiang, L., Machmuller, M. B., Mohan, J., Panetta, A. M., Reich, P. B., Reinsch, S., Wang, X., Allison, S. D., Bamminger, C., Bridgham, S., Collins, S. L., de Dato, G., Eddy, W. C., Enquist, B. J., Estiarte, M., Harte, J., Henderson, A., Johnson, B. R., Larsen, K. S., Luo, Y., Marhan, S., Melillo, J. M., Penuelas, J., Pfeifer-Meister, L., Poll, C., Rastetter, E., Reinmann, A. B., Reynolds, L. L., Schmidt, I. K., Shaver, G. R., Strong, A. L., Suseela, V., and Tietema, A.: Temperature response of soil respiration largely unaltered with experimental warming, P. Natl. Acad. Sci. USA, 113, 13797-13802, https://doi.org/10.1073/pnas.1605365113, 2016.

Chen, J., Luo, Y., Xia, J., Wilcox, K. R., Cao, J., Zhou, X., Jiang, L., Niu, S., Estera, K. Y., Huang, R., Wu, F., Hu, T., Liang, J., Shi, Z., Guo, J., and Wang, R.-W.: Warming effects on ecosystem carbon fluxes are modulated by plant functional types, Ecosystems, 20, 515-526, https://doi.org/10.1007/s10021-016-0035-6, 2016.

Chou, W. W., Silver, W. L., Jackson, R. D., Thompson, A. W., and Allen-Diaz, B.: The sensitivity of annual grassland carbon cycling to the quantity and timing of rainfall, Global Change Biol., 14, 1382-1394, https://doi.org/10.1111/j.13652486.2008.01572.x, 2008.

Davidson, E. A. and Janssens, I. A.: Temperature sensitivity of soil carbon decomposition and feedbacks to climate change, Nature, 440, 165-173, https://doi.org/10.1038/nature04514, 2006.

Davidson, E. A., Trumbore, S. E., and Amundson, R.: Soil warming and organic carbon content, Nature, 408, 789-790, https://doi.org/10.1038/35048672, 2000.

Deyn, G. B. D., Cornelissen, J. H. C., and Bardgett, R. D.: Plant functional traits and soil carbon sequestration in contrasting biomes, Ecol. Lett., 11, 516-531, https://doi.org/10.1111/j.14610248.2008.01164.x, 2008.

Duval, T. P. and Radu, D. D.: Effect of temperature and soil organic matter quality on greenhouse-gas production from temperate poor and rich fen soils, Ecol. Eng., 114, 66-75, https://doi.org/10.1016/j.ecoleng.2017.05.011, 2018.

Eliasson, P. E., McMurtrie, Pepper, D. A., Stromgren, M., Linder, S., and Agren, G. I.: The response of heterotrophic $\mathrm{CO}_{2}$ flux to soil warming, Glob. Change Biol., 11, 167-181, 2005.

Epstein, H. E., Burke, I. C., and Lauenroth, W. K.: Response of the shortgrass steppe to changes in rainfall seasonality, Ecosystems, 2, 139-150, 1999.

Fischer, H., Eckhardt, K.-U., Meyer, A., Neumann, G., Leinweber, P., Fischer, K., and Kuzyakov, Y.: Rhizodeposition of maize: short-term carbon budget and composition, J. Plant. Nutr. Soil. Sc., 173, 67-79, https://doi.org/10.1002/jpln.200800293, 2010.

Fisk, M. C., Ruether, K. F., and Yavitt, J. B.: Microbial activity and functional composition among northern peatland ecosystems, Soil Biol. Biochem., 35, 591-602, https://doi.org/10.1016/S0038-0717(03)00053-1, 2003.

Fontaine, S., Bardoux, G., Abbadie, L., and Mariotti, A.: Carbon input to soil may decrease soil carbon content, Ecol. Lett., 7, 314 320, https://doi.org/10.1111/j.1461-0248.2004.00579.x, 2004.

Gillooly, J. F., Brown, J. H., West, G. B., Savage, V. M., and Charnov, E. L.: Effects of size and temperature on metabolic rate,
Science, 293, 2248, https://doi.org/10.1126/science.1061967, 2001.

Hartley, I. P. and Ineson, P.: Substrate quality and the temperature sensitivity of soil organic matter decomposition, Soil Biol. Biochem., 40, 1567-1574, https://doi.org/10.1016/j.soilbio.2008.01.007, 2008.

Heimann, M. and Reichstein, M.: Terrestrial ecosystem carbon dynamics and climate feedbacks, Nature, 451, 289-292, https://doi.org/10.1038/nature06591, 2008.

Hinsinger, P., Bengough, A. G., Vetterlein, D., and Young, I. M.: Rhizosphere: biophysics, biogeochemistry and ecological relevance, Plant Soil, 321, 117-152, https://doi.org/10.1007/s11104008-9885-9, 2009.

Hogberg, P. and Read, D. J.: Towards a more plant physiological perspective on soil ecology, Trends Ecol. Evol., 21, 548-554, 2006.

Hollister, R. D., Webber, P. J., Nelson, F. E., and Tweedie, C. E.: Soil Thaw and Temperature Response to Air Warming Varies by Plant Community: Results from an Open-top Chamber Experiment in Northern Alaska, Arct. Antarct. Alp. Res., 38, 206-215, https://doi.org/10.1657/15230430(2006)38[206:STATRT]2.0.CO;2, 2006.

Hopkins, F. M., Filley, T. R., Gleixner, G., Lange, M., Top, S. M., and Trumbore, S. E.: Increased belowground carbon inputs and warming promote loss of soil organic carbon through complementary microbial responses, Soil Biol. Biochem., 76, 57-69, https://doi.org/10.1016/j.soilbio.2014.04.028, 2014.

Jackson, R. B., Lajtha, K., Crow, S. E., Hugelius, G., Kramer, M. G., and Piñeiro, G.: The ecology of soil carbon: pools, vulnerabilities, and biotic and abiotic controls, Annu. Rev. Ecol. Evol. S., 48, 419-445, https://doi.org/10.1146/annurev-ecolsys112414-054234, 2017.

Karhu, K., Auffret, M. D., Dungait, J. A., Hopkins, D. W., Prosser, J. I., Singh, B. K., Subke, J. A., Wookey, P. A., Agren, G. I., Sebastia, M. T., Gouriveau, F., Bergkvist, G., Meir, P., Nottingham, A. T., Salinas, N., and Hartley, I. P.: Temperature sensitivity of soil respiration rates enhanced by microbial community response, Nature, 513, 81-84, https://doi.org/10.1038/nature13604, 2014.

Kirschbaum, M. U. F.: The temperature dependence of soil organic matter decomposition, and the effect of global warming on soil organic C storage, Soil Biol. and Biochem., 27, 753-760, https://doi.org/10.1016/0038-0717(94)00242-S, 1995.

Leifeld, J. and Fuhrer, J.: The temperature response of $\mathrm{CO}_{2}$ production from bulk soils and soil fractions is related to soil organic matter quality, Biogeochemistry, 75, 433-453, https://doi.org/10.1007/s10533-005-2237-4, 2005.

Lenth, R.: lsmeans: Least-Squares Means, version 2.30, available at: https://CRAN.R-project.org/package=lsmeans (last access: 30 April 2018), 2018.

Li, G., Kim, S., Han, S., Chang, H., and Son, Y.: Effect of soil moisture on the response of soil respiration to open-field experimental warming and precipitation manipulation, Forests, 8, 56, https://doi.org/10.3390/f8030056, 2017.

Lin, D., Xia, J., and Wan, S.: Climate warming and biomass accumulation of terrestrial plants: a meta-analysis, New Phytol., 188, 187-198, https://doi.org/10.1111/j.1469-8137.2010.03347.x, 2010.

Lu, M., Zhou, X., Yang, Q., Li, H., Luo, Y., Fang, C., Chen, J., Yang, X., and Li, B.: Responses of ecosystem carbon cycle to 
experimental warming: a meta-analysis, Ecology, 94, 726-738, https://doi.org/10.1890/12-0279.1, 2013.

Luo, Y:: Terrestrial carbon-cycle feedback to climate warming, Annu. Rev. Ecol. Evol. S., 38, 683-712, https://doi.org/10.1146/annurev.ecolsys.38.091206.095808, 2007.

Luo, Y., Wan, S. Q., Hui, D. F., and Wallace, L. L.: Acclimatization of soil respiration to warming in a tall grass prairie, Nature, 413 , 622-625, https://doi.org/10.1038/35098065, 2001.

Melillo, J. M., Frey, S. D., DeAngelis, K. M., Werner, W. J., Bernard, M. J., Bowles, F. P., Pold, G., Knorr, M. A., and Grandy, A. S.: Long-term pattern and magnitude of soil carbon feedback to the climate system in a warming world, Science, 358, 101, https://doi.org/10.1126/science.aan2874, 2017.

Metcalfe, D. B., Fisher, R. A., and Wardle, D. A.: Plant communities as drivers of soil respiration: pathways, mechanisms, and significance for global change, Biogeosciences, 8, 2047-2061, https://doi.org/10.5194/bg-8-2047-2011, 2011.

Millar, D. J., Cooper, D. J., Dwire, K. A., Hubbard, R. M., and von Fischer, J.: Mountain peatlands range from $\mathrm{CO}_{2}$ sinks at high elevations to sources at low elevations: Implications for a changing climate, Ecosystems, 20, 416-432, https://doi.org/10.1007/s10021-016-0034-7, 2016.

Moinet, G. Y. K., Hunt, J. E., Kirschbaum, M. U. F., Morcom, C. P., Midwood, A. J., and Millard, P.: The temperature sensitivity of soil organic matter decomposition is constrained by microbial access to substrates, Soil Biol. Biochem., 116, 333-339, https://doi.org/10.1016/j.soilbio.2017.10.031, 2018.

Ontl, T. A. and Schulte, L. A.: Soil carbon storage, Nature Education Knowledge, 3, 35, 2012.

Parton, W. J., Schimel, D. S., Cole, C. V., and Ojima, D. S.: Analysis of Factors Controlling Soil Organic Matter Levels in Great Plains Grasslands, Soil Sci. Soc. Am. J., 51, 1173-1179, https://doi.org/10.2136/sssaj1987.03615995005100050015x, 1987.

Pendall, E., Osanai, Y. U. I., Williams, A. L., and Hovenden, M. J.: Soil carbon storage under simulated climate change is mediated by plant functional type, Global Change Biol., 17, 505-514, https://doi.org/10.1111/j.1365-2486.2010.02296.x, 2011.

Phillips, R. P., Finzi, A. C., and Bernhardt, E. S.: Enhanced root exudation induces microbial feedbacks to $\mathrm{N}$ cycling in a pine forest under long-term $\mathrm{CO}_{2}$ fumigation, Ecol. Lett., 14, 187-194, https://doi.org/10.1111/j.1461-0248.2010.01570.x, 2011.

Rillig, M. C., Wright, S. F., Nichols, K. A., Schmidt, W. F., and Torn, M. S.: Large contribution of arbuscular mycorrhizal fungi to soil carbon pools in tropical forest soils, Plant and Soil, 233, 167-177, https://doi.org/10.1023/A:1010364221169, 2001.

Rustad, L., Campbell, J., Marion, G., Norby, R., Mitchell, M., Hartley, A., Cornelissen, J., Gurevitch, J., and Gcte, N.: A meta-analysis of the response of soil respiration, net nitrogen mineralization, and aboveground plant growth to experimental ecosystem warming, Oecologia, 126, 543-562, https://doi.org/10.1007/s004420000544, 2001.

Saleska, S. R., Shaw, M. R., Fischer, M. L., Dunne, J. A., Still, C. J., Holman, M. L., and Harte, J.: Plant community composition mediates both large transient decline and predicted long-term recovery of soil carbon under climate warming, Global Biogeochem. Cy., 16, 1055, https://doi.org/10.1029/2001GB001573, 2002.
Schimel, D. S., Braswell, B. H., Holland, E. A., McKeown, R., Ojima, D. S., Painter, T. H., Parton, W. J., and Townsend, A. R.: Climatic, edaphic, and biotic controls over storage and turnover of carbon in soils, Global Biogeochem. Cy., 8, 279-293, https://doi.org/10.1029/94GB00993, 1994.

Schlesinger, W. H.: Biogeochemistry: an analysis of global change, Second edition ed., Academic Press, California, 1997.

Schlesinger, W. H. and Andrews, J. A.: Soil respiration and the global carbon cycle, Biogeochemistry, 48, 7-20, 2000.

Shahzad, T., Chenu, C., Genet, P., Barot, S., Perveen, N., Mougin, C., and Fontaine, S.: Contribution of exudates, arbuscular mycorrhizal fungi and litter depositions to the rhizosphere priming effect induced by grassland species, Soil Biol. Biochem., 80, 146155, https://doi.org/10.1016/j.soilbio.2014.09.023, 2015.

Sheik, C. S., Beasley, W. H., Elshahed, M. S., Zhou, X., Luo, Y., and Krumholz, L. R.: Effect of warming and drought on grassland microbial communities, The ISME J., 5, 1692-1700, https://doi.org/10.1038/ismej.2011.32, 2011.

Sierra, C. A., Trumbore, S. E., Davidson, E. A., Vicca, S., and Janssens, I.: Sensitivity of decomposition rates of soil organic matter with respect to simultaneous changes in temperature and moisture, J. Adv. Model. Earth Sy., 7, 335-356, https://doi.org/10.1002/2014ms000358, 2015.

Song, B., Niu, S., Luo, R., Luo, Y., Chen, J., Yu, G., Olejnik, J., Wohlfahrt, G., Kiely, G., Noormets, A., Montagnani, L., Cescatti, A., Magliulo, V., Law, B. E., Lund, M., Varlagin, A., Raschi, A., Peichl, M., Nilsson, M. B., and Merbold, L.: Divergent apparent temperature sensitivity of terrestrial ecosystem respiration, J. Plant Ecol., 7, 419-428, https://doi.org/10.1093/jpe/rtu014, 2014.

Suseela, V., Conant, R. T., Wallenstein, M. D., and Dukes, J. S.: Effects of soil moisture on the temperature sensitivity of heterotrophic respiration vary seasonally in an old-field climate change experiment, Glob. Change Biol., 18, 336-348, https://doi.org/10.1111/j.1365-2486.2011.02516.x, 2012.

Syed, K. H., Flanagan, L. B., Carlson, P. J., Glenn, A. J., and Van Gaalen, K. E.: Environmental control of net ecosystem $\mathrm{CO}_{2}$ exchange in a treed, moderately rich fen in northern Alberta, Agr. Forest Meteorol., 140, 97-114, https://doi.org/10.1016/j.agrformet.2006.03.022, 2006.

Trumbore, S. E., Chadwick, O. A., and Amundson, R.: Rapid exchange between soil carbon and atmospheric carbon dioxide driven by temperature change, Science, 272, 393, https://doi.org/10.1126/science.272.5260.393, 1996.

van der Wal, A., and de Boer, W.: Dinner in the dark: Illuminating drivers of soil organic matter decomposition, Soil Biol. Biochem., 105, 45-48, https://doi.org/10.1016/j.soilbio.2016.11.006, 2017.

van Gestel, N., Shi, Z., van Groenigen, K. J., Osenberg, C. W., Andresen, L. C., Dukes, J. S., Hovenden, M. J., Luo, Y., Michelsen, A., Pendall, E., Reich, P. B., Schuur, E. A. G., and Hungate, B. A.: Predicting soil carbon loss with warming, Nature, 554, E4E5, https://doi.org/10.1038/nature25745, 2018.

Van Nuland, M. E., Wooliver, R. C., Pfennigwerth, A. A., Read, Q. D., Ware, I. M., Mueller, L., Fordyce, J. A., Schweitzer, J. A., Bailey, J. K., and Fox, C.: Plant-soil feedbacks: connecting ecosystem ecology and evolution, Funct. Ecol., 30, 1032-1042, https://doi.org/10.1111/1365-2435.12690, 2016. 
Wan, S. and Luo, Y.: Substrate regulation of soil respiration in a tallgrass prairie: results of a clipping and shading experiment, Global Biogeochem. Cy., 17, 1054, https://doi.org/10.1029/2002GB001971, 2003.

Wan, S., Hui, D., Wallace, L., and Luo, Y.: Direct and indirect effects of experimental warming on ecosystem carbon processes in a tallgrass prairie, Global Biogeochem. Cy., 19, GB2014, https://doi.org/10.1029/2004gb002315, 2005.

Wang, J., Sun, J., Xia, J., He, N., Li, M., and Niu, S.: Soil and vegetation carbon turnover times from tropical to boreal forests, Funct. Ecol., 32, 71-82, https://doi.org/10.1111/13652435.12914, 2017.

Wang, X., Liu, L., Piao, S., Janssens, I. A., Tang, J., Liu, W., Chi, Y., Wang, J., and $\mathrm{Xu}$, S.: Soil respiration under climate warming: differential response of heterotrophic and autotrophic respiration, Global Change Biol., 20, 3229-3237, https://doi.org/10.1111/gcb.12620, 2014.

Wardle, D. A., Bonner, K. I., Barker, G. M., Yeates, G. W., Nicholson, K. S., Bardgett, R. D., Watson, R. N., and Ghani, A.: Plant removals in perennial grassland: vegetation dynamics, decomposers, soil biodiversity, and ecosystem properties, Ecol. Monogr., 69, 535-568, 1999.

Wardle, D. A., Bardgett, R. D., Klironomos, J. N., Setala, H., van der Putten, W. H., and Wal, D. H.: Ecological linkages between aboveground and belowground biota, Science, 304, 1629-1633, https://doi.org/10.1126/science.1094875, 2004.

Wu, Z., Dijkstra, P., Koch, G. W., Peñuelas, J., and Hungate, B. A.: Responses of terrestrial ecosystems to temperature and precipitation change: a meta-analysis of experimental manipulation, Global Change Biol., 17, 927-942, https://doi.org/10.1111/j.1365-2486.2010.02302.x, 2011.
Xue, K., Yuan, M. M., Xie, J., Li, D., Qin, Y., Hale, L. E., Wu, L., Deng, Y., He, Z., Van Nostrand, J. D., Luo, Y., Tiedje, J. M., and Zhou, J.: Annual removal of aboveground plant biomass alters soil microbial responses to warming, MBio, 7, e00976-16, https://doi.org/10.1128/mBio.00976-16, 2016.

Yin, H., Li, Y., Xiao, J., Xu, Z., Cheng, X., and Liu, Q.: Enhanced root exudation stimulates soil nitrogen transformations in a subalpine coniferous forest under experimental warming, Global Change Biol., 19, 2158-2167, https://doi.org/10.1111/gcb.12161, 2013.

Zhang, N., Liu, W., Yang, H., Yu, X., Gutknecht, J. L., Zhang, Z., Wan, S., and Ma, K.: Soil microbial responses to warming and increased precipitation and their implications for ecosystem C cycling, Oecologia, 173, 1125-1142, https://doi.org/10.1007/s00442-013-2685-9, 2013.

Zhou, X., Sherry, R. A., An, Y., Wallace, L. L., and Luo, Y.: Main and interactive effects of warming, clipping, and doubled precipitation on soil $\mathrm{CO}_{2}$ efflux in a grassland ecosystem, Global Biogeochem. Cy., 20, GB1003, https://doi.org/10.1029/2005GB002526, 2006.

Zhou, Y., Li, M.-H., Cheng, X.-B., Wang, C.-G., Fan, A. N., Shi, L.X., Wang, X.-X., and Han, S.: Soil respiration in relation to photosynthesis of Quercus mongolica trees at elevated $\mathrm{CO}_{2}$, PLOS ONE, 5, e15134, https://doi.org/10.1371/journal.pone.0015134, 2010.

Zhu, B. and Cheng, W.: Rhizosphere priming effect increases the temperature sensitivity of soil organic matter decomposition, Global Change Biol., 17, 2172-2183, https://doi.org/10.1111/j.1365-2486.2010.02354.x, 2011. 